\title{
Effects of Dietary Fat Intake on HDL Metabolism
}

\author{
Hidekatsu Yanai ${ }^{\mathrm{a}, \mathrm{c}}$, Hisayuki Katsuyama ${ }^{\mathrm{a}}$, Hidetaka Hamasaki ${ }^{\mathrm{a}}$, Shinichi Abe ${ }^{\mathrm{b}}$, Norio Tada ${ }^{\mathrm{b}}$, Akahito Sako $^{\mathrm{a}}$
}

\begin{abstract}
High-density lipoprotein (HDL) is a lipoprotein which has anti-atherogenic property by reversing cholesterol transport from the peripheral tissues to liver. Low HDL-cholesterol (HDL-C) as well as high lowdensity lipoprotein-cholesterol (LDL-C) is associated with the development of coronary heart diseases (CHD). Various epidemiological studies have suggested that the development of CHD increase in individuals with less than $40 \mathrm{mg} / \mathrm{dL}$ of HDL-C. In spite of accumulation of evidences suggesting a significant association between low HDL-C and CHD, effects of dietary factors on HDL metabolism remained largely unknown. We reviewed published articles about effects of dietary fat intake on HDL metabolism. The substitution of fatty acids (FA) for carbohydrates is beneficially associated with HDL metabolism. Monounsaturated FA intake may not affect HDL-C. Trans-FA is significantly associated with reduction of HDL-C, and is also adversely related with total cholesterol/HDL-C. Fish oils consumption, especially docosahexaenoic acid consumption, may be favorably associated with HDL metabolism. Although plant sterols and stanols may not affect HDL-C, policosanol intake is associated with a clinically significant decrease in the LDL/HDL ratio.
\end{abstract}

Keywords: Coronary heart diseases; Fatty acids; Fish oils; Highdensity lipoprotein; Plant sterols

\section{Introduction}

Atherogenic dyslipidemia is characterized as elevated serum levels of triglyceride (TG) and low-density lipoprotein-cholesterol (LDL-C), and low serum levels of high-density lipoprotein-cholesterol (HDL-C). Since HDL is an anti-atherogenic

Manuscript accepted for publication November 17, 2014

aDepartment of Internal Medicine, National Center for Global Health and Medicine, Kohnodai Hospital, Chiba, Japan

${ }^{\mathrm{b}}$ The Jikei University School of Medicine, Tokyo, Japan

${ }^{\mathrm{c} C}$ Corresponding Author: Hidekatsu Yanai, Department of Internal Medicine, National Center for Global Health and Medicine, Kohnodai Hospital, 1-7-1 Kohnodai, Chiba 272-8516, Japan. Email: dyanai@hospk.ncgm.go.jp

doi: http://dx.doi.org/10.14740/jocmr2030w lipoprotein which plays a role in reversing cholesterol transport from the peripheral tissues to the liver, low HDL-C level induces the development of coronary heart diseases (CHD) [1, 2], and cerebrovascular diseases (CVD) [3].

A significant influence of low HDL-C on CHD and CVD has been widely known; however, roles of dietary factors for HDL metabolism remained largely unknown. We reviewed published articles about effects of dietary factors, especially dietary fat intake on HDL metabolism. We regarded systematic reviews and meta-analyses as important articles in this review.

\section{Effects of Various Fatty Acids (FA) Intake on HDL Metabolism}

Mensink et al calculated the effect of changes in carbohydrate and FA intake on serum lipids, reviewing 27 controlled trials published between 1970 and 1991 (Table 1) [4-8]. They found that all types of FA ingestion elevated HDL-C when substituted for carbohydrates, but the effect decreased with increasing unsaturation of FA. Another meta-analysis was performed to examine the relationship between milk fat containing dairy foods and cardiovascular risk factors [5]. This study indicated that a diet higher in saturated FA (SFA) from whole milk and butter increases HDL-C when substituted for carbohydrates or unsaturated FA (USFA). Results from these two studies indicate that the substitution of FA for carbohydrates is beneficially associated with HDL metabolism, and also suggest that SFA is favorably associated with HDL-C. Mensink et al performed the meta-analysis of 60 selected trials and calculated the effects of the amount and type of fat on the total cholesterol (TC)/HDL-C [6]. TC/HDL did not change if carbohydrates replaced SFA, but it decreased if cis-USFA replaced SFA. The effect on TC/HDL of replacing trans-FA (TFA) with a mix of carbohydrates and cis-USFA was almost twice as large as that of replacing SFA. Briefly, TC/HDL-C was reduced by the replacement of TFA with SFA by 0.019; the replacement with cis-monounsaturated FA (MUFA) by 0.048 ; and the replacement with cis-polyunsaturated FA (PUFA) by 0.054 . Coronary risk was reduced most effectively when TFA and SFA were replaced with cis-USFA.

Salas-Salvado et al reviewed the clinical trials on humans that evaluate how mixtures of conjugated linoleic acid (CLA) isomers administered as supplements or CLA-enriched prod- 
Table 1. Meta-Analyses for Effects of Various FA Intake on HDL Metabolism

\begin{tabular}{|c|c|c|c|}
\hline Authors & Study design & Subjects & Results/conclusions \\
\hline Mensink et al [4] & $\begin{array}{l}\text { Effects of changes in carbohydrate } \\
\text { and FA intake on serum lipids }\end{array}$ & Twenty-seven controlled trials & $\begin{array}{l}\text { All FA elevated HDL- } \\
\mathrm{C} \text { when substituted } \\
\text { for carbohydrates }\end{array}$ \\
\hline Huth et al [5] & $\begin{array}{l}\text { The relationship between milk fat contain- } \\
\text { ing dairy foods and cardiovascular health }\end{array}$ & $\begin{array}{l}\text { The published research including } \\
\text { observational studies and short-term } \\
\text { intervention studies, and reviews }\end{array}$ & $\begin{array}{l}\text { A diet higher in SFA } \\
\text { from whole milk and } \\
\text { butter increases HDL- } \\
\mathrm{C} \text { when substituted for } \\
\text { carbohydrates or USFA }\end{array}$ \\
\hline Mensink et al [6] & $\begin{array}{l}\text { Effects of the amount and type of fat } \\
\text { on TC/HDL-C and on other lipids }\end{array}$ & Sixty controlled trials & $\begin{array}{l}\text { Replacement of carbo- } \\
\text { hydrates with SFA did } \\
\text { not change TC/HDL-C, } \\
\text { but replacement with } \\
\text { cis-USFA decreased. } \\
\text { Replacement of TFA } \\
\text { with SFA decreased TC/ } \\
\text { HDL-C by } 0.019 \text {; with } \\
\text { cis-MUFA, by } 0.048 \text {; and } \\
\text { with cis-PUFA, by } 0.054\end{array}$ \\
\hline Salas-Salvado et al [7] & Effects of CLA on metabolic parameters & $\begin{array}{l}\text { Healthy humans or patients } \\
\text { with overweight, obesity, meta- } \\
\text { bolic syndrome, or diabetes }\end{array}$ & $\begin{array}{l}\text { CLA isomers de- } \\
\text { creases HDL-C }\end{array}$ \\
\hline Wendland et al [8] & $\begin{array}{l}\text { Effects of dietary supplementation with } \\
\text { ALA on cardiovascular risk markers }\end{array}$ & $\begin{array}{l}\text { Fourteen studies with minimum } \\
\text { treatment duration of } 4 \text { weeks }\end{array}$ & $\begin{array}{l}\text { There was a small but } \\
\text { clinically unimpor- } \\
\text { tant decrease in HDL } \\
(0.39 \mathrm{mg} / \mathrm{dL}, 95 \% \mathrm{CI} \text { : } \\
-0.77-0.00, \mathrm{P}<0.01)\end{array}$ \\
\hline
\end{tabular}

ALA: alpha linolenic acid; CI: confidence interval; CLA: conjugated linoleic acid; FA: fatty acids; HDL-C: high-density lipoprotein- cholesterol; SFA: saturated fatty acids; USFA: unsaturated fatty acids; TC: total cholesterol; TFA: trans-fatty acids.

ucts can affect plasma lipids, and they found that some of studies have observed that various CLA isomers decreases HDL-C [7]. Wendland et al performed systematic review and metaanalysis to determine whether dietary supplementation with alpha linolenic acid (ALA) can modify coronary risk factors [8]. There was a small but clinically non-significant decrease in HDL-C due to ALA ingestion.

Schwingshackl et al analyzed long-term, randomized controlled trials (RCTs) to investigate the effects of MUFA on cardiovascular risk factors (Table 2) [9-11]. Dietary regimens with a high amount of MUFA $(>12 \%)$ were compared to those with $\leq 12 \%$. A total of 12 studies met the inclusion criteria. HDL-C was not significantly affected by the percentage of MUFA.

Recently, TFA has been reported to adversely affect cardiovascular health, and Mozaffarian et al reviewed the evidence for effects of TFA consumption on CHD risks. They found that reduction of HDL-C by TFA consumption was observed in both controlled trials and observational studies [10]. These effects were most prominent in comparison with cis-USFA, and adverse effect of TFA on TC/HDL-C was also found in comparison with SFA. Mozaffarian et al performed a meta-analysis of the effects of TFA on serum lipids in controlled dietary trials. In controlled trials, each 1\% energy replacement of TFA with SFA, MUFA and PUFA decreased TC/HDL-C by 0.31 ,
0.54 and 0.67 , respectively [11].

\section{Effects of Fish Oils Intake on HDL Metabolism}

Fish oils have been widely reported to be a useful supplement to reduce serum TG levels in individuals with hyperlipidemia; however, effects of fish oils on serum HDL-C remained obscure. Lewis et al reviewed all RCTs from 1994 to 2003 which addressed the efficacy of long-chain omega-3 FA for dyslipidemia, and they found that 10 studies reported longchain omega-3 FA to be effective in the treatment of hypertriglyceridemia (Table 3) [12-16]. According to accumulation of the data obtained from 10 studies, the average increase in HDL-C was $10 \%$. Eslick et al performed the meta-analysis to quantitatively evaluate all RCTs of fish oils in hyperlipidemic individuals [13]. Their final analysis comprised of 47 studies showed that taking fish oils (daily intake of $3.25 \mathrm{~g}$ of eicosapentaenoic acid (EPA) and/or docosahexaenoic acid (DHA)) produced a modest increase in HDL-C $(0.39 \mathrm{mg} / \mathrm{dL}, 95 \% \mathrm{CI}$ : $0.00-0.77)$ which was not statistically significant. Pei et al performed a systematic review and meta-analysis of the effect of n-3 PUFA consumption on plasma lipids in patients with end-stage renal disease [14]. They reviewed evidences obtained from 10 RCTs including 557 patients with end-stage re- 
Table 2. Meta-Analyses for the Effects of MUFA and TFA on HDL Metabolism

\begin{tabular}{|c|c|c|c|}
\hline Authors & Study design & Subjects & Results/conclusions \\
\hline Schwingshackl et al [9] & $\begin{array}{l}\text { Effects of MUFA on cardiovascular } \\
\text { risk factors. Dietary regimens with a } \\
\text { high amount of MUFA }(>12 \%) \text { were } \\
\text { compared to those with } \leq 12 \% \text {. }\end{array}$ & Twelve studies & No effect on HDL-C \\
\hline Mozaffarian et al [10] & Effects of TFA consumption on CHD & $\begin{array}{l}\text { Medline publications examining } \\
\text { TFA consumption and CHD risk } \\
\text { factors or outcomes in humans }\end{array}$ & $\begin{array}{l}\text { The effects of TFA } \\
\text { consumption on risk } \\
\text { factors most consistently } \\
\text { seen in both controlled } \\
\text { trials and observational } \\
\text { studies included re- } \\
\text { duction of HDL-C }\end{array}$ \\
\hline Mozaffarian et al [11] & $\begin{array}{l}\text { Quantitative estimates of CHD effects } \\
\text { if a person's PHVO consumption were } \\
\text { to be replaced with alternative fats and } \\
\text { oils based on randomized dietary trials } \\
\text { and prospective observational studies }\end{array}$ & $\begin{array}{l}\text { Meta-analyses of the effects of } \\
\text { TFAs on blood lipids and lipopro- } \\
\text { teins in controlled dietary trials } \\
\text { and associations of habitual TFA } \\
\text { consumption with CHD outcomes } \\
\text { in prospective cohort studies }\end{array}$ & $\begin{array}{l}\text { In controlled trials, each } \\
1 \% \text { energy replacement } \\
\text { of TFA with SFA, MUFA } \\
\text { and PUFA, respec- } \\
\text { tively, decreased the TC/ } \\
\text { HDL-C by } 0.31,0.54 \\
\text { and } 0.67 \text {, respectively }\end{array}$ \\
\hline
\end{tabular}

CHD: coronary heart diseases; MUFA: monounsaturated fatty acids; HDL-C: high-density lipoprotein-cholesterol; PHVO: partially hydrogenated vegetable oils; PUFA: polyunsaturated fatty acids, SFA: saturated fatty acids; TC: total cholesterol.

nal disease. The pooled analysis revealed that n-3 PUFA intake elevated HDL-C by $9.67 \mathrm{mg} / \mathrm{dL}$, which was not statistically significant. Certain algae contain the n-3 FA, DHA. Bernstein et al examined the relationship between algal oil supplementation and CHD risk factors, by conducting a systematic review of RCTs published between 1996 and 2011 [15]. They identi- fied 11 RCTs with 485 healthy participants, and the median dose of algal DHA was $1.68 \mathrm{~g} /$ day. The pooled estimate for the change in HDL-C was $2.71 \mathrm{mg} / \mathrm{dL}$ (95\% CI: 1.93 - 3.87), suggesting that DHA supplementation from algal oil increases HDL-C in healthy individuals. Wei et al performed a metaanalysis of RCTs of monotherapy with EPA $(n=10)$, DHA

Table 3. Meta-Analyses for Effects of Fish Oils Intake on HDL Metabolism

\begin{tabular}{|c|c|c|c|}
\hline Authors & Study design & Subjects & Results/conclusions \\
\hline Lewis et al [12] & $\begin{array}{l}\text { Efficacy of long-chain omega- } 3 \\
\text { FA as secondary agents for preven- } \\
\text { tion of hypertriglyceridemia }\end{array}$ & Ten studies & $\begin{array}{l}\text { Average increase in } \\
\text { HDL was } 10 \%\end{array}$ \\
\hline Eslick et al [13] & $\begin{array}{l}\text { Effects of fish oils on serum li- } \\
\text { pids in hyperlipidemic subjects }\end{array}$ & $\begin{array}{l}\text { Forty-seven studies, subjects taking fish oils } \\
\text { (daily intake of } 3.25 \mathrm{~g} \text { of EPA and/or DHA) }\end{array}$ & $\begin{array}{l}\text { Taking fish oils produced } \\
\text { very slight increases } \\
\text { in HDL }(0.39 \mathrm{mg} / \mathrm{dL} \text {, } \\
95 \% \text { CI: } 0.00-0.77)\end{array}$ \\
\hline Bernstein et al [15] & $\begin{array}{l}\text { Certain algae contain the DHA. } \\
\text { The relation between algal oil } \\
\text { supplementation and cardio- } \\
\text { vascular disease risk factors }\end{array}$ & $\begin{array}{l}\text { Eleven randomized controlled tri- } \\
\text { als with } 485 \text { healthy participants }\end{array}$ & $\begin{array}{l}\text { The pooled estimate for } \\
\text { the change in HDL-C } \\
\text { was } 2.71 \mathrm{mg} / \mathrm{dL}(95 \% \\
\text { CI: } 1.93-3.87)\end{array}$ \\
\hline
\end{tabular}

CI: confidence interval; DHA: docosahexaenoic acid; EPA: eicosapentaenoic acid; FA: fatty acids; HDL-C: high-density lipoprotein-cholesterol; PUFA: polyunsaturated fatty acids. 
Table 4. Meta-Analyses for Effects of Plant Sterols and Stanols on HDL Metabolism

\begin{tabular}{|c|c|c|c|}
\hline Authors & Study design & Subjects & Results/conclusions \\
\hline Talati et al [17] & $\begin{array}{l}\text { Comparison between the effect of plant } \\
\text { sterols vs. plant stanols on serum lipids }\end{array}$ & $\begin{array}{l}\text { Healthy subjects or patients } \\
\text { with hypercholesterolemia, } \\
14 \text { studies }(n=531)\end{array}$ & $\begin{array}{l}\text { No statistically or clini- } \\
\text { cally significant difference } \\
\text { between plant sterols } \\
\text { and plant stanols in their } \\
\text { abilities to modify HDL-C }\end{array}$ \\
\hline Seppo et al [18] & $\begin{array}{l}\text { Effects of ingestion of low-fat milk } \\
\text { products enriched with plant stanol esters } \\
\text { ( } 2 \mathrm{~g} / \text { day) for } 5 \text { weeks on serum lipids }\end{array}$ & $\begin{array}{l}\text { A total of } 199 \text { hypercho- } \\
\text { lesterolemic subjects }\end{array}$ & $\begin{array}{l}\text { There were no significant } \\
\text { differences between the } \\
\text { groups in pooled HDL-C }\end{array}$ \\
\hline Moruisi et al [19] & $\begin{array}{l}\text { Efficacy of plant sterols/stanols } \\
\text { for } 4 \text { weeks to } 3 \text { months in lower- } \\
\text { ing TC and LDL-C in FH subjects }\end{array}$ & $\begin{array}{l}\text { Heterozygous FH patients, } \\
\text { aged } 2-69 \text { years old }\end{array}$ & HDL-C were not affected \\
\hline Chen et al [20] & $\begin{array}{l}\text { Comparison of the efficacy and } \\
\text { safety of plant sterols and stanols } \\
\text { with policosanol in serum lipids }\end{array}$ & $\begin{array}{l}\text { A total of } 4,596 \text { patients } \\
\text { from } 52 \text { eligible studies }\end{array}$ & $\begin{array}{l}\text { Policosanol affected } \\
\text { HDL-C more fa- } \\
\text { vorably than plant } \\
\text { sterols and stanols }\end{array}$ \\
\hline
\end{tabular}

FH: familial hypercholesterolemia; HDL-C: high-density lipoprotein-cholesterol; LDL-C: low-density lipoprotein-cholesterol; TC: total cholesterol.

$(\mathrm{n}=17)$, or EPA vs. DHA $(\mathrm{n}=6)$ [16]. Compared with placebo, DHA raised HDL-C (4.49 mg/dL; 95\% CI: 3.50 - 5.48), whereas EPA did not raise HDL-C.

\section{Effects of Plant Sterols and Stanols on HDL Me- tabolism}

Plant sterols and stanols have a similar chemical structure and function to cholesterol. Therefore, plant sterols and stanols ingestion are sometimes suggested to beneficially modify serum lipids. Plant sterols have a higher degree of absorption as compared with plant stanols. Talati et al performed a meta-analysis of RCTs to compare the effect of plant sterols with plant stanols on serum lipid levels in healthy individuals and also patients with hypercholesterolemia (Table 4) [17-20]. Fourteen studies $(n=531)$ met the inclusion criteria. There was no statistically or clinically significant difference between plant sterols and plant stanols in their abilities to modify HDL-C. Seppo et al conducted a meta-analysis of four RCTs to evaluate the effect of low-fat milk products enriched with plant stanol esters on serum lipids [18]. Each stanol-ester-enriched milk product provided daily $2 \mathrm{~g}$ of stanols, and the intervention period was 5 weeks. A total of 199 hypercholesterolemic subjects were included. There were no significant differences between the placebo group and the stanol group in pooled HDL-C. Moruisi et al conducted a systematic review that investigates the efficacy of plant sterols and stanols in modifying serum lipids in subjects with familial hypercholesterolemia (FH) [19]. The subjects studied were heterozygous FH subjects, aged 2 - 69 years old with baseline TC and LDL-C concentrations of $270.7 \mathrm{mg} /$ $\mathrm{dL}$ and $208.8 \mathrm{mg} / \mathrm{dL}$, respectively. Result showed that plant sterols and stanols did not affect HDL-C. Policosanol is a very long chain aliphatic alcohol derived from the wax constituent of plants [21]. The original policosanol supplement has been approved as a cholesterol-lowering drug in over 25 countries. Chen et al performed systematic review and meta-analysis of
RCTs, to compare the efficacy and safety of plant sterols and stanols as well as policosanol in the treatment of CHD [20]. A total of 4,596 patients from 52 eligible studies were included for their analysis. Policosanol affected HDL-C more favorably than plant sterols and stanols. Policosanol induced a clinically significant decrease in the LDL/HDL ratio.

\section{Conclusion}

The substitution of FA for carbohydrates is beneficially associated with HDL metabolism. MUFA intake may not affect HDLC. TFA is significantly associated with reduction of HDL-C, and is also adversely related with TC/HDL-C, coronary risks. Fish oils consumption, especially DHA consumption, may be favorably associated with HDL metabolism. Although plant sterols and stanols may not affect HDL-C, policosanol intake is associated with a clinically significant decrease in the LDL/ HDL ratio.

\section{Acknowledgement}

This work was supported by a grant from the National Center for Global Health and Medicine (25-203).

\section{Conflict of Interest}

The authors declare that they have no competing interests.

\section{References}

1. Kitamura A, Iso H, Naito Y, Iida M, Konishi M, Folsom AR, Sato S, et al. High-density lipoprotein cholesterol and premature coronary heart disease in urban Japanese 
men. Circulation. 1994;89(6):2533-2539.

2. Yokokawa H, Yasumura S, Tanno K, Ohsawa M, Onoda T, Itai K, Sakata K, et al. Serum low-density lipoprotein to high-density lipoprotein ratio as a predictor of future acute myocardial infarction among men in a 2.7-year cohort study of a Japanese northern rural population. J Atheroscler Thromb. 2011;18(2):89-98.

3. Okamura T, Hayakawa T, Kadowaki T, Kita Y, Okayama A, Ueshima $\mathrm{H}$. The inverse relationship between serum high-density lipoprotein cholesterol level and all-cause mortality in a 9.6-year follow-up study in the Japanese general population. Atherosclerosis. 2006;184(1):143150 .

4. Mensink RP, Katan MB. Effect of dietary fatty acids on serum lipids and lipoproteins. A meta-analysis of 27 trials. Arterioscler Thromb. 1992;12(8):911-919.

5. Huth PJ, Park KM. Influence of dairy product and milk fat consumption on cardiovascular disease risk: a review of the evidence. Adv Nutr. 2012;3(3):266-285.

6. Mensink RP, Zock PL, Kester AD, Katan MB. Effects of dietary fatty acids and carbohydrates on the ratio of serum total to HDL cholesterol and on serum lipids and apolipoproteins: a meta-analysis of 60 controlled trials. Am J Clin Nutr. 2003;77(5):1146-1155.

7. Salas-Salvado J, Marquez-Sandoval F, Bullo M. Conjugated linoleic acid intake in humans: a systematic review focusing on its effect on body composition, glucose, and lipid metabolism. Crit Rev Food Sci Nutr. 2006;46(6):479-488.

8. Wendland E, Farmer A, Glasziou P, Neil A. Effect of alpha linolenic acid on cardiovascular risk markers: a systematic review. Heart. 2006;92(2):166-169.

9. Schwingshackl L, Strasser B, Hoffmann G. Effects of monounsaturated fatty acids on cardiovascular risk factors: a systematic review and meta-analysis. Ann Nutr Metab. 2011;59(2-4):176-186.

10. Mozaffarian D, Aro A, Willett WC. Health effects of trans-fatty acids: experimental and observational evidence. Eur J Clin Nutr. 2009;63(Suppl 2):S5-21.

11. Mozaffarian D, Clarke R. Quantitative effects on cardiovascular risk factors and coronary heart disease risk of replacing partially hydrogenated vegetable oils with other fats and oils. Eur J Clin Nutr. 2009;63(Suppl 2):S22-33.

12. Lewis A, Lookinland S, Beckstrand RL, Tiedeman ME. Treatment of hypertriglyceridemia with omega-3 fatty acids: a systematic review. J Am Acad Nurse Pract. 2004;16(9):384-395.

13. Eslick GD, Howe PR, Smith C, Priest R, Bensoussan A. Benefits of fish oil supplementation in hyperlipidemia: a systematic review and meta-analysis. Int $\mathrm{J}$ Cardiol. 2009;136(1):4-16.

14. Pei J, Zhao Y, Huang L, Zhang X, Wu Y. The effect of n-3 polyunsaturated fatty acids on plasma lipids and lipoproteins in patients with chronic renal failure--a meta-analysis of randomized controlled trials. J Ren Nutr. 2012;22(6):525-532.

15. Bernstein AM, Ding EL, Willett WC, Rimm EB. A metaanalysis shows that docosahexaenoic acid from algal oil reduces serum triglycerides and increases HDL-cholesterol and LDL-cholesterol in persons without coronary heart disease. J Nutr. 2012;142(1):99-104.

16. Wei MY, Jacobson TA. Effects of eicosapentaenoic acid versus docosahexaenoic acid on serum lipids: a systematic review and meta-analysis. Curr Atheroscler Rep. 2011;13(6):474-483.

17. Talati R, Sobieraj DM, Makanji SS, Phung OJ, Coleman CI. The comparative efficacy of plant sterols and stanols on serum lipids: a systematic review and meta-analysis. J Am Diet Assoc. 2010;110(5):719-726.

18. Seppo L, Jauhiainen T, Nevala R, Poussa T, Korpela R. Plant stanol esters in low-fat milk products lower serum total and LDL cholesterol. Eur J Nutr. 2007;46(2):111117.

19. Moruisi KG, Oosthuizen W, Opperman AM. Phytosterols/stanols lower cholesterol concentrations in familial hypercholesterolemic subjects: a systematic review with meta-analysis. J Am Coll Nutr. 2006;25(1):41-48.

20. Chen JT, Wesley R, Shamburek RD, Pucino F, Csako G. Meta-analysis of natural therapies for hyperlipidemia: plant sterols and stanols versus policosanol. Pharmacotherapy. $2005 ; 25(2): 171-183$.

21. Marinangeli CP, Jones PJ, Kassis AN, Eskin MN. Policosanols as nutraceuticals: fact or fiction. Crit Rev Food Sci Nutr. 2010;50(3):259-267. 